\title{
Penile reconstruction using mesenchymal stem cells ${ }^{1}$
}

\author{
Marcus Laks', Luiz Gonzaga Freitas-Filho"I, Kleber Sayeg ${ }^{I I}$, Mila Torii Correia Leite ${ }^{\mathrm{IV}}$, Luciana Cristina TeixeiraV
}

DOI: http://dx.doi.org/10.1590/S0102-865020150080000003

IPhD, Postdoctoral Fellow, Surgical Sciences, Division of Pediatric Surgery, Department of Surgery, Universidade Federal de São Paulo (UNIFESP), Brazil. Design of the study, technical procedures, manuscript writing, supervised all phases of the study.

IIFull Professor, Division of Pediatric Surgery, Department of Surgery, UNIFESP, Sao Paulo-SP, Brazil. Acquisition and interpretation of data, design and supervised all phases of the study, English language.

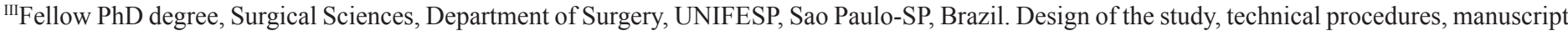
writing.

Iv PhD, Associate Professor, Division of Pediatric Surgery, Department of Surgery, UNIFESP, Sao Paulo-SP, Brazil. Design of the study, technical procedures, manuscript writing.

${ }^{\vee}$ Fellow Master degree, Surgical Sciences, Department of Surgery, UNIFESP, Sao Paulo-SP, Brazil. Design of the study, acquisition and interpretation of data, manuscript writing.

\section{ABSTRACT}

PURPOSE: To compare the reconstruction of corpus cavernosum segments when seeded with mesenchymal stem cells and when stem cells are infused intravenously.

METHODS: Sixteen New Zealand rabbits were submitted to reconstruction of the corpus cavernosum and distributed in Group A - decellularized matrices, Group B - decellularized matrices seeded with mesenchymal stem cells Group C - decellularized matrices submitted to intravenous infusion of mesenchymal stem cells. The mesenchymal stem cells were obtained by bone marrow aspiration. The venous filling aspect of the distal end of the corpus cavernosum was evaluated and the specimens were submitted to histological analisis and to immunohistochemistry. Cavernosometry was done in one animal of each group

RESULTS: Three animals on B and three animals on $\mathrm{C}$ presented full filling of distal end of the corpus cavernosum. No animals in A

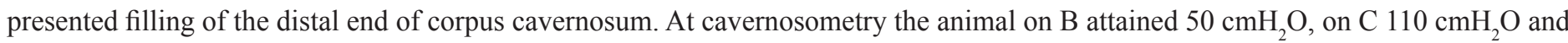
on A $20 \mathrm{cmH}_{2} \mathrm{O}$. Trabeculae forming cavernous sinuses were found in groups B and C.

CONCLUSION: The reconstruction of corpus cavernosum using descellularized matrices and mesenchymal stem cells, either by intravenous injection or directly seeded is possible, with growth of corpus cavernosum-like tissue.

Key words: Tissue Engineering. Stem Cells. Regenerative Medicine. Penis. Rabbits. 


\section{Introduction}

Penile reconstruction is a complex procedure, however necessary in the treatment of congenital anomalies that may involve from total agenesis of the organ to anomalies such as the exstrophy-epispadias complex, sexual differentiation disorders and proximal hypospadias ${ }^{1}$. Acquired anomalies such as in cases of traumas, infections, malignancies or even in cases of sex reassignment may also require genital reconstruction. The objective is to reconstruct an esthetically acceptable phallus that allows for adequate intercourse.

For full reconstruction of the penis, different tactics have been used, almost all involving the confection of skin flaps and using complex microsurgery techniques, that inevitably lead to large morbidity, both in the donor and receptor areas and, although possibly giving the penis a reasonable appearance, rarely do they allow for functional recovery of the organ ${ }^{2-4}$.

Tissue engineering is currently an alternative to the functional reconstruction of the penis. In an experimental study using rabbits, homologous corpora cavernosa were decellularized, seeded sequentially by autologous smooth muscle cells and endothelial cells, enabling replacement of a $0,7 \mathrm{~cm}$ entire crossseccional segment. Growth of the smooth musculature and an intense neovascularization network were observed in the morphological evaluation ${ }^{5}$.

When corpus cavernosum are absent or no native tissue is available to initiate cellular culture, stem cells may come in as a good alternative. Embryonic and other pluripotent stem cells have the inconvenience of forming tumors when implanted "in vivo", in addition to ethic matters involved in their usage. Among the adult stem cells, mesenchymal cells are the ones mostly studied. They can be easily obtained through bone marrow aspiration ${ }^{6}$. The most important characteristic of these cells is believed, actually, to be their capacity to maintain homeostasis and tissues integrity ${ }^{7-9}$. They are kept in a quiescent condition in specific areas, called niches, where they would be able to make normal cell replacement of that specific tissue and, should a lesion occur, they would have capacity to migrate to the site of the aggression, attracted by a series of chemokines repopulating the damaged organs ${ }^{10}$. The immunomodulatory role of mesenchymal stem cells has already been demonstrated. They can suppress the immune response by inhibiting the proliferation of $\mathrm{T}$ lymphocytes, B lymphocytes ${ }^{11,12}$, "natural killer" cells and damaging the function of antigen presentation of dendritic cell ${ }^{13-15}$, through a paracrine secretion mechanism ${ }^{9}$.

As they are infused "in vivo" they migrate to the damaged tissue areas ${ }^{16}$ and are not recognized by the host's immune system for failing to express major histocompatibility complex (MHC) class II antigens ${ }^{17-18}$. Systemic infusion of mesenchymal stem cells was used with good results in the graftversus-host disease following transplantation of hematopoietic stem cells, with no difference among syngeneic or allogeneic stem cell transplantation ${ }^{19}$.

In this study we used tissue engineering techniques to construct a corpus cavernosum segment by using decellularized matrices repopulated with allogeneic mesenchymal stem cells either directly seeded on the matrix or intravenously infused.

\section{Methods}

The experiment was submitted to the Research Ethics Committee of the Universidade Federal de São Paulo - Escola Paulista de Medicina (UNIFESP-EPM) and approved under protocol number: CEP 0924/08.

Sixteen New Zealand rabbits aged six months, approximately, obtained from CEDEME (Centro de Desenvolvimento de Modelos Experimentais) the animal facility from UNIFESP were submitted to reconstruction of the corpus cavernosum and allotted into three groups: Group A $(n=4)$ using decellularized homologous matrix Group B ( $n=6)$ Using decellularized homologous matrix seeded with mesenchymal stem cells Group C $(n=6)$ Using decellularized homologous matrix followed by intravenous infusion of mesenchymal stem cells.

\section{Procedures}

The animals were given pre-anesthetic medication with acepromazine maleate $(2.4 \mathrm{mg} / \mathrm{Kg})$ followed by anesthetic medication $2 \%$ xylazine chloride $(2.0 \mathrm{~mL})$ and $1 \%$ ketamine chloride $(1 \mathrm{~mL})$ by intramuscular route. Penile anesthetic block was performed with $0.25 \%$ bupivacaine chloride $(2.0 \mathrm{~mL})$. The same anesthetic procedures were used for the bone marrow punctures.

\section{Preparation of the collagen matrix}

Corpora cavernosa were taken from sacrificed rabbits obtained from commercial slaughterhouses. We harvested the discarded corpora tissue within few minutes after death and were kept in PBS on ice until descellularization process was initiated ${ }^{5}$.

They were sectioned into segments of approximately $7 \mathrm{~mm}$ and washed with distilled water in a magnetic stirrer flask for 24 hours at $4{ }^{\circ} \mathrm{C}$ and then treated with $1 \%$ Triton x 100 (Sigma Chemical CO, Saint Louis, MO, USA) and 0.1\% ammonium 
hydroxide in fresh distilled water for 14 days. They were washed with distilled water for 48 hours and put into phosphate buffered saline (PBS) for 24 hours. Histological tests were performed using hematoxylin-eosin to confirm acellularity, and picrosirius red stain to demonstrate preservation of the collagen fibers. The matrices were kept in $87 \%$ glycerol at $4^{\circ} \mathrm{C}$. Before used the matrices were washed with PBS and incubated with DMEM (Dulbecco's modified Eagle's medium- Sigma Chemical Company, St Louis, MO, USA) with 10\% fetal bovine serum (FBS) (Fetal Bovine Serum - Gibco, Carlsbad - CA, USA) 10.000 Ul/L of penicillin and $50 \mathrm{mg} / \mathrm{L}$ streptomycin for 2 days, for glycerol to be removed.

\section{Culture of mesenchymal stem cells}

Bone marrow was aspirated from iliac crest of five New Zealand male rabbits under aseptic conditions. These animals were posteriorly used in the penile reconstruction takin care to not make autologous seeding or infusion. The mononuclear cells were separated by density gradient, by using Histopaque solution (Sigma-Aldrich, St. Louis, MO, USA) and placed in $25 \mathrm{~cm}^{2}$ flasks containing DMEM with $15 \%$ FBS and kept in incubators at $37^{\circ} \mathrm{C}$ with $5 \% \mathrm{CO}_{2}$. The cultures were expanded until reaching the number of cells necessary either to seed on the matrices or for intravenous infusion according to the animal group. Cells from the third to the sixth passage were used.

\section{Cell seeding on the collagen matrix}

Mesenchymal stem cells were seeded on the decellularized matrix in a $20 \times 10^{6}$ cells $/ \mathrm{mL}$ concentration, using a $1 \mathrm{~mL}$ syringe and a $23 \mathrm{G}$ needle. The culture was kept in a flask with DMEM supplemented with $10 \% \mathrm{FBS}$, in an incubator, for 7 days until implantation time. The culture medium was changed every $24 \mathrm{hs}$.

\section{Corpora cavernosa implant}

A longitudinal incision on the dorsal face of the penis was performed and the central portion of the corpora cavernosa dissected, preserving the neurovascular bundles. The corpora cavernosa was cross-sectioned and the penile urethra was dissected and isolated. The $7 \mathrm{~mm}$-long matrix was inserted between the two stumps of the corpus cavernosum and sutured with separate 6-0 polyglycolic acid stitches. A 6-0 polypropylene suture marked both anastomosis sites (Figure 1).

\section{Intravenous infusion of mesenchymal stem cells}

The mesenchymal stem cells were intravenously infused in a concentration of $0.5-1 \times 10^{6}$ cells $/ \mathrm{Kg}$, in $1.5 \mathrm{~mL}$ PBS by auricular vein puncture. Infusions were performed on day one, eight and twenty postoperatively.

\section{Postoperative evaluations}

All animals were assessed postoperatively in week 12 .

\section{Macroscopic aspect}

Cavernous filling of the distal end of corpora cavernosa was observed and every animal was photographed.

\section{Cavernosometry}

One animal from every group underwent cavernosometry and all animals have been evaluated before surgical procedure. For normal measures we used animal before surgical proceeding. The penis was clamped in its proximal region and the corpus cavernosum was punctured in its distal portion with a 25 Gauge scalp. Saline solution was infused at $1 \mathrm{~mL} / \mathrm{min}$ (ST670 volumetric infunsion pump; Samtronic, Sao Paulo, Brazil). Proximal puncture was performed with a 21 Gauge scalp, which was connected to the transducer of the urodynamic device (Dynapack MPX816Dynamed, Sao Paulo, Brazil) to measure the pressure of the corpora cavernosa.

\section{Histomorphometric evaluation}

The animals underwent euthanasia in postoperative week twelve through anesthetic overdose. As Normal group we used animals from slaughterhouse before decellularization. The penis was excised, fixed in $10 \%$ formaldehyde, and cut into fivemicrometer longitudinal sections stained with hematoxylin-eosin and analyzed by optical microscopy. For immunohistochemistry smooth muscle cells were labeled with monoclonal anti a-actin (Clone 1A4, Cell Marque Rocklin, CA - USA) antibodies and endothelial cells with polyclonal anti Factor VIII (BIOSB Santa Barbara, CA 93117 - USA) antibodies. It has been observed the architecture of venous sinus formation. 


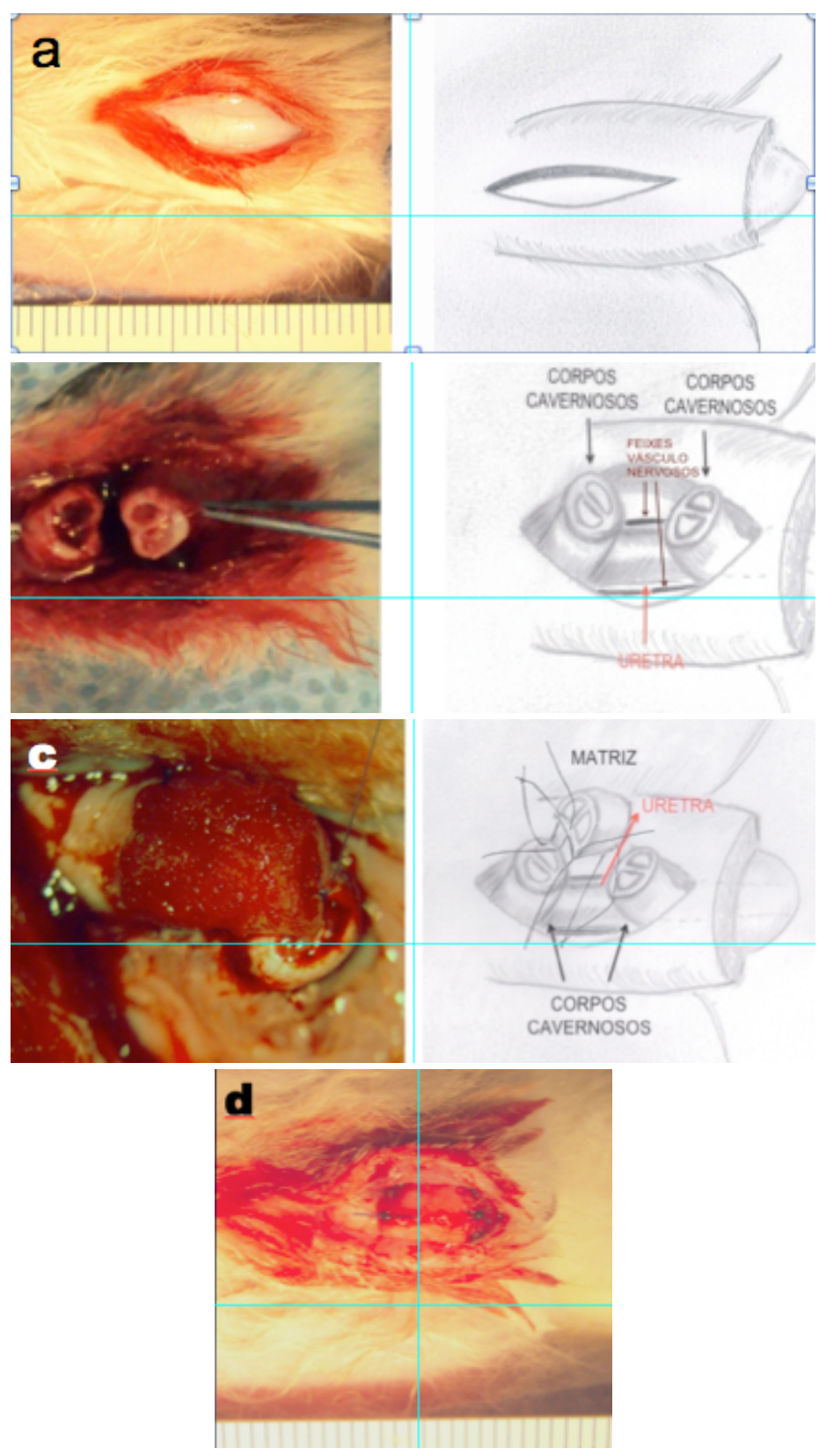

FIGURE 1 - a. Incision on the dorsal aspect of the penis. b. Cross-section of corpus cavernosum preserving neurovascular bundles and urethra. c. Matrix insertion and suture. d. Matrix in place.

\section{Results}

Sixteen surgical interventions were performed, with one death in group $\mathrm{C}$ on postoperative day ten due to wound infection.

\section{Macroscopic evaluation}

No animal in group A was found to show filling of the distal end of the corpus cavernosum. Three animals in group B and three in group C was found to show filling of the distal end of corpus cavernosum (Figure 2). All animals had augmented diameter of the corpora cavernosa in the graft area (Figure 3).
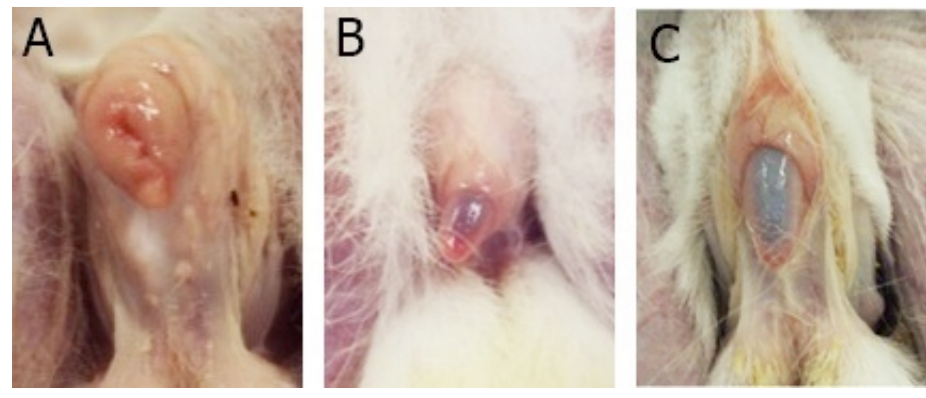

FIGURE 2 - Filling of distal end of corpora cavernosa. A. Group A matrix without cells. B. Group B matrix with cells seeded. C. Group C matrix with intravenous infused cells.

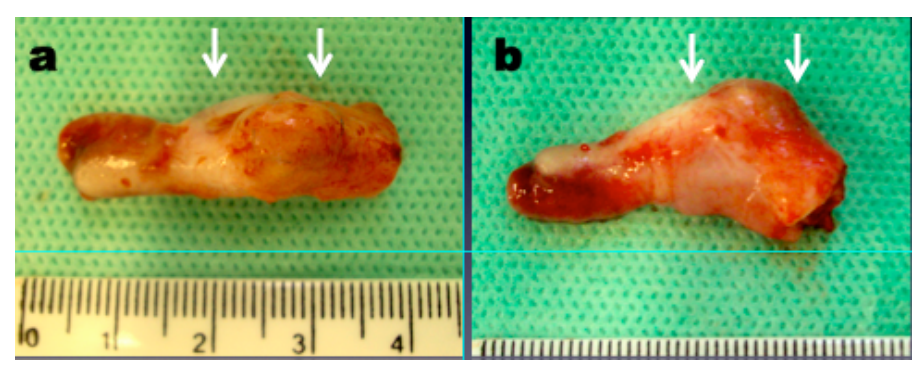

FIGURE 3 - Neocorpora showing augmented diameter of graft intake animal from group C. a. Dorsal aspect. b. Lateral aspect.

\section{Histological and immunohistochemical evaluation}

Histological evaluation showed that the animals in the three groups had healing tissue with fibrosis. Areas similar to trabeculae forming cavernous sinuses with neovascularization, surrounded by scar reaction were found in the animals in groups B and C. In the immunohistochemical evaluation with anti a-actin and anti-Factor VIII antibodies, all animals had formation of smooth muscle tissue with neovascularization; however, we observed areas of organized smooth muscle bundles forming cavernous sinuses in the animals in groups B and C. The animals in group A showed disorganized areas of smooth muscle tissue overlapping fibrous tissue areas, rarely forming cavernous sinuses (Figures 4 and 5).

\section{Cavernosometry}

The pressure determined in normal animals was around $305 \mathrm{cmH}_{2} \mathrm{O}$. The animal from group A had no significant pressure increase, with a peak of $20 \mathrm{cmH}_{2} \mathrm{O}$. The animal on group $\mathrm{B}$ had a pressure peak of $50 \mathrm{cmH}_{2} \mathrm{O}$ and on group $\mathrm{C} 110 \mathrm{cmH}_{2} \mathrm{O}$ (Figure 6). 

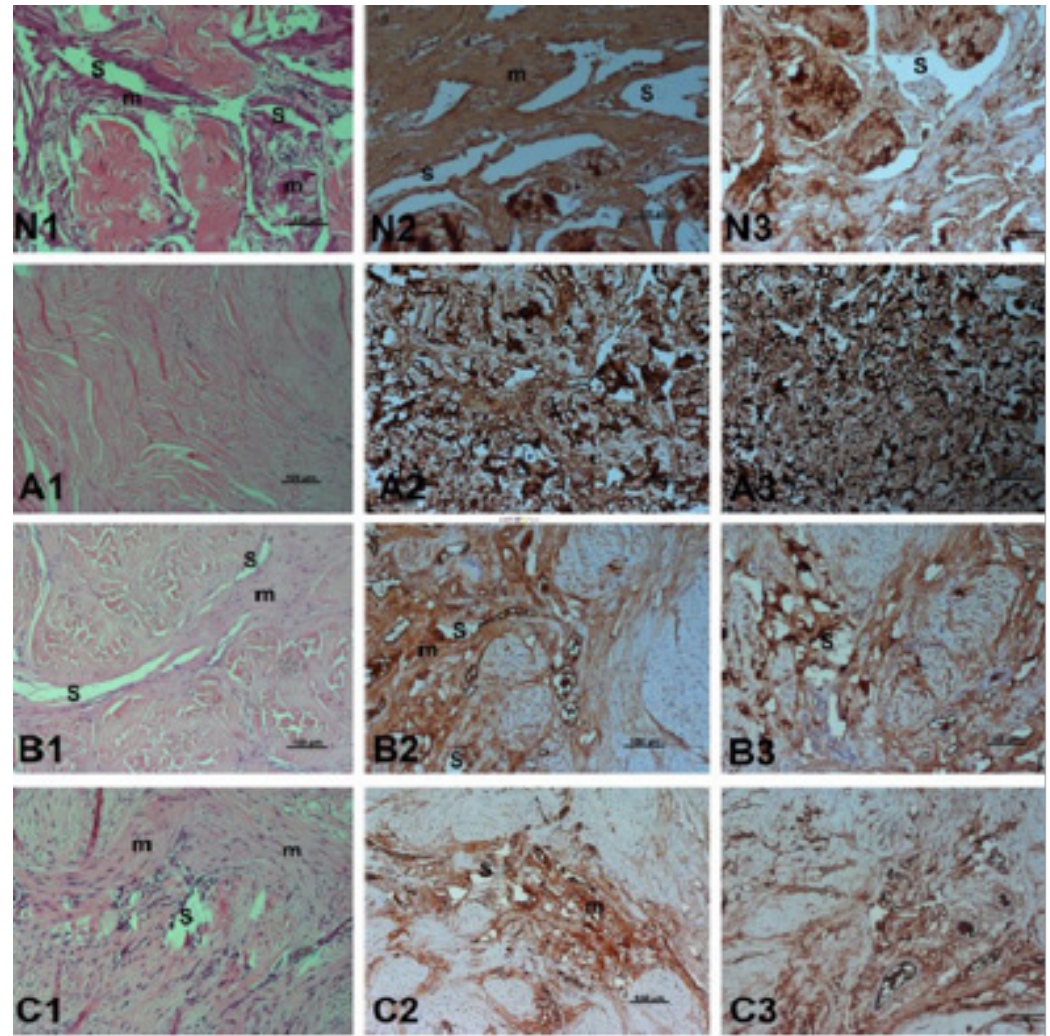

FIGURE 4 - Histological sections $\mathbf{N}=$ Normal rabbit. $\mathbf{A}=$ Matrix without cells, $\mathbf{B}=$ Matrix with cells seeded, $\mathbf{C}=$ Matrix with intravenous infused cells. $\mathbf{1}=\mathrm{H} \& \mathrm{E}, \mathbf{2}=$ antibody anti $\alpha$-actina, $\mathbf{3}=$ antibody anti factor VIII. $\mathbf{s}=$ cavernous sinus, $\mathbf{m}=$ smooth muscle. Original magnification $\mathrm{x} 100$.
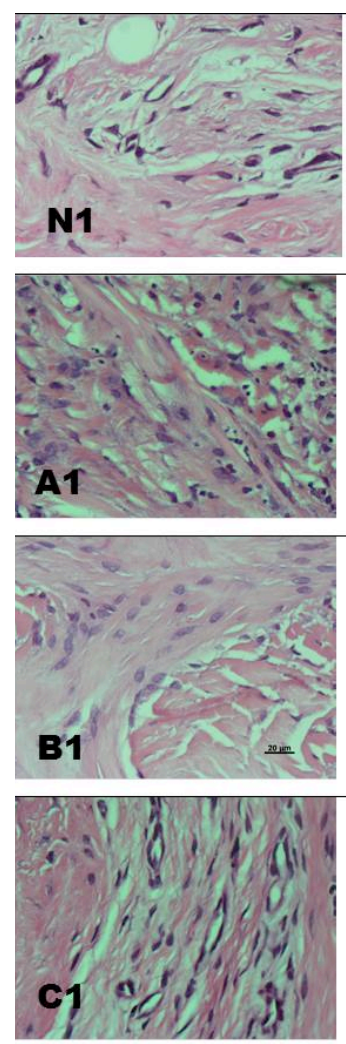
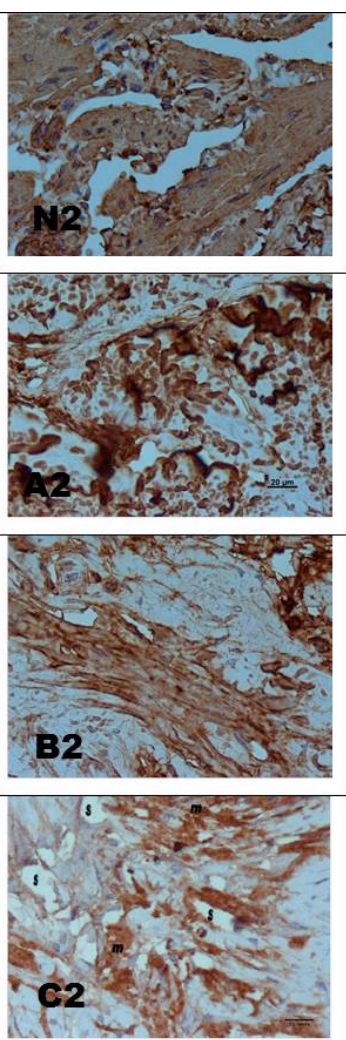
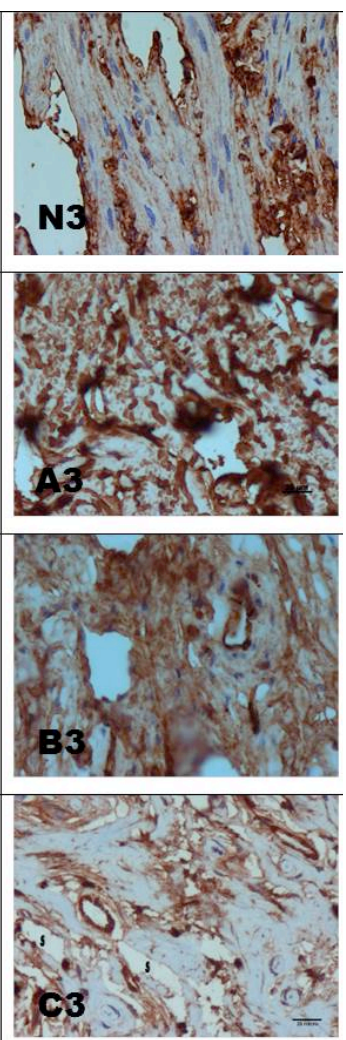

FIGURE 5 - Histological sections $\mathbf{N}=$ Normal rabbit. $\mathbf{A}=$ Matrix without cells, $\mathbf{B}=$ Matrix with cells seeded, $\mathbf{C}=$ Matrix with intravenous infused cells. $\mathbf{1}=$ H\&E, $\mathbf{2}=$ antibody anti $\alpha$-actina, $\mathbf{3}=$ antibody anti factor VIII. $\mathbf{s}=$ cavernous sinus, $\mathbf{m}=$ smooth muscle. Original magnification $\mathrm{x} 400$. 


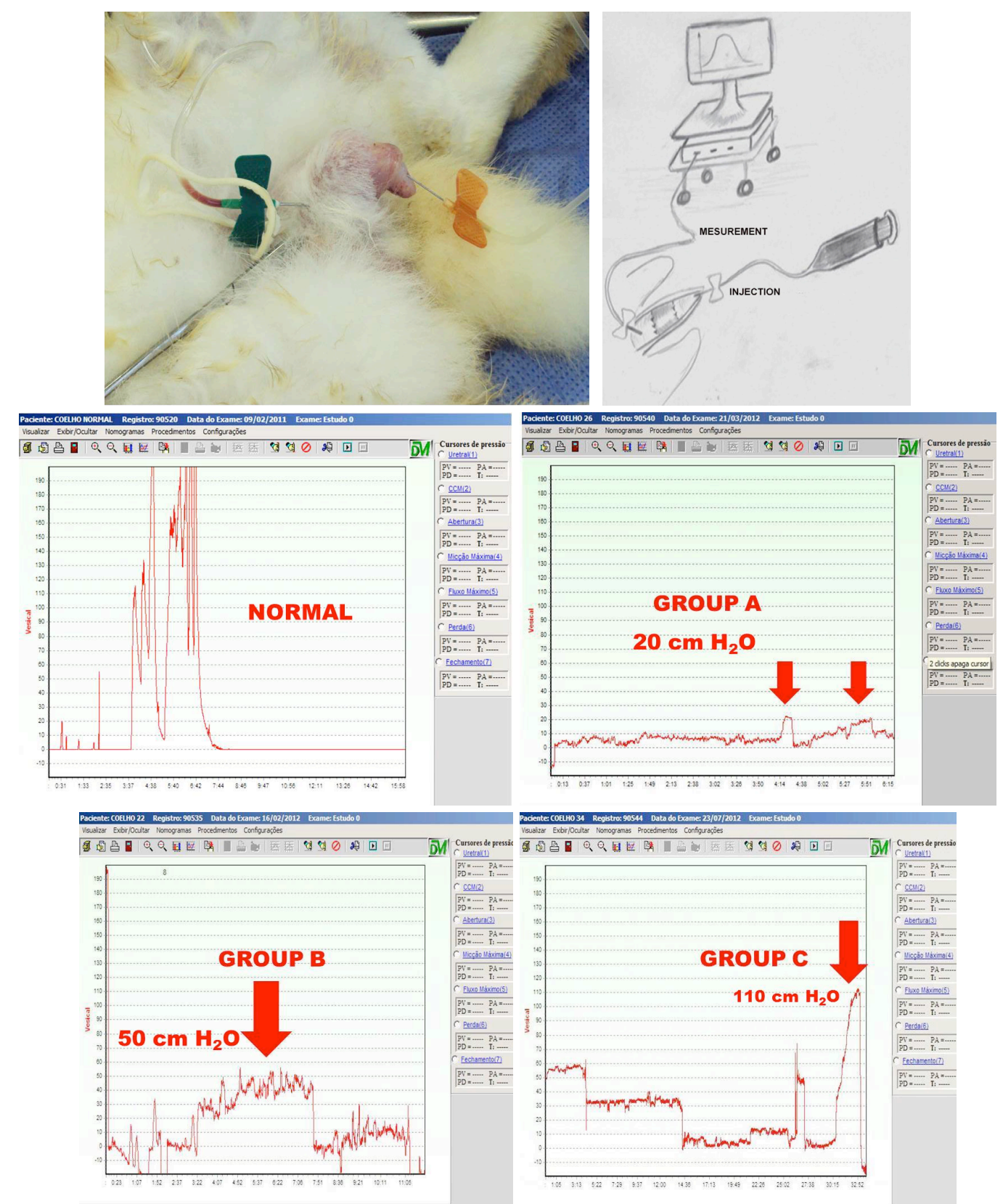

FIGURE 6 - Cavernosometry. Animals from groups A, B and C. Normal - Measures performed before the surgical procedure

\section{Discussion}

Scarcity of autologous tissue adequate for corpora cavernosa anatomic and functional reconstruction is the major technical difficulty for adequate penile reconstruction. Regenerative medicine may be a viable alternative and mesenchymal stem cells have been used for their capacity of differentiation into other mesenchymal cells, and of immunomodulation with consequent reduction of the inflammatory process $^{7,8,12,19}$. In this study mesenchymal stem cells either seeded directly on the decellularized matrix or intravenously infused, were able to partially reconstruct cavernous sinuses similar to those of the native corpus cavernosum.

Trials using tissue engineering techniques for penile reconstruction at first used synthetic matrices ${ }^{20,21}$. Although formation of well vascularized smooth muscle tissue occurred, the intricate anatomy of the cavernous tissue could not be reproduced.

The solution found was to use the corpus cavernosum of cadaveric donors that once submitted to the decellularization process, provided the matrices for the receptor's cells to grow. Those structures kept the proper architecture of the penis, and maintained bioactive substances that favor cell migration, adherence, proliferation and differentiation ${ }^{22-24}$. 
In this study the rabbits' corpus cavernosum decellularized matrices were used to find out whether the topic or systemic use of allogeneic bone marrow mesenchymal stem cells could reconstruct the organ anatomy, therefore avoiding the use of autologous cells.

The dynamic studies of the distribution of infused labeled mesenchymal stem cells showed that $70 \%$ of them first accumulate in the pulmonary capillaries that work as a large barrier ${ }^{25,26}$. After forty-eight hours, they could be found in the liver, lungs and kidneys ${ }^{25}$. Cells migration to damaged tissues is favored by chemokines produced by those tissues and their specific receptors facilitate cell adherence and infiltration ${ }^{8}$.

In previous research our group investigated the action of mesenchymal stem cells in rats undergoing bladder augmentation with bladder acellular matrices (BAM). In one of the animal groups mesenchymal stem cells were seeded on the BAM before augmentation and in the other group the animals received stem cell infusions on postoperative day one, eight and fifteen. Although in both groups the normal architecture of the bladder was restored, only the groups in which stem cells were infused showed growing of nervous fillets. Notwithstanding such results, labeled stem cells couldn't be demonstrated in the bladder when the organ was examined on postoperative day 28 . Those cells are most likely to act rapidly at the site where they migrate to, through immunomodulatory activity ${ }^{27}$.

No reports on the use of those cells in penile reconstruction experiments were found, although the use of stem cells taken from striated muscle has been reported by Ji et al. ${ }^{28}$. In this case a small fusiform longitudinal graft was used. Evaluation made in the second, fourth and sixth postoperative months showed that smooth muscle fibers were progressively organized around the collagen in the stem cell grafts, clearly forming cavernous sinuses, whereas the animals in which no stem cells were implanted (control group), although presenting muscle growth, did so in a disorganized fashion, overlapping the new collagen fibers ${ }^{28}$. In a recent study transfected cells were added to this experimental design to produce VEGF. A larger number of capillaries in the graft was found in the second month postoperative evaluation ${ }^{29}$.

In this study a $7 \mathrm{~mm}$ long segment of the corpus cavernosum was reconstructed, subjecting the graft to different levels of ischemia depending on its distance from the proximal anastomosis. Blood passage through the graft with the filling of the distal portion of the corpus cavernosum (Figure 1) could be seen in three animals in group B and in three animals in group C. Smooth muscle fibers grew in all three groups, and the groups in which stem cells were used, either seeded directly on the matrix or systemically infused, showed a better organized muscle tissue, with clear formation of smooth muscle trabeculae forming cavernous sinuses, heterogeneously intermixed by fibrosis areas (Figure 2). In group A muscle fibers were formed, arranged in a disorganized fashion, overlapping the fibrous tissue, with no clear formation of cavernous sinuses. It may be speculated that stem cells, through an immunomodulatory paracrine action, were important to keep neoformed tissue organized.

Just one animal from every group underwent cavernosometry, so as to avoid any possible alteration later in the histomorphetic study of the further rabbits. The animal from group $\mathrm{C}$ had the highest pressure, followed by the animal from group B. The animal from group A (Figure 3) had no significant pressure increase.

The studies to follow should use animal models that allow for vascular anastomosis for a more adequate vascularization of the new penis, while the use of VEGF, FGF and of other growth factors may enable a more exuberant vascular network to be developed in the graft, or even a more adequate neural network to be established.

\section{Conclusion}

Reconstruction of the corpus cavernosum by using decellularized matrices with intravenously infused or directly seeded mesenchymal stem cells was possible, with grown tissue similar to that of the native corpus cavernosum. No significant differences were found, either when stem cells were directly seeded on the matrix or intravenously infused.

\section{References}

1. Silver RI, Yang A, Ben-Chaim J, Jeffs RD, Gearhart JP. Penile length in adulthood after exstrophy reconstruction. J Urol. 1997 Mar;157(3):999-1003. PMID: 9072636.

2. Timsit M-O, Mouriquand PE, Ruffion A, Bouillot A, Dembelé D, Mejean A, Lallou F, Leriche A, Morel-Journel N. Use of forearm free-flap phalloplasty in bladder exstrophy adults. BJU Int. 2009;103(10):1418-21.doi: 10.1111/j.1464-410x.2008.0820.x.

3. Monstrey S, Hoebeke P, Selvaggi G, Celeuman P, van Landuyt K, Blondeel P, Hamdi M, Roche N, Weyers S, De Cuypere G. Penile reconstruction: is the radial forearm flap really the standard technique? Plast Reconstr Surg. 2009 Aug;124(2):510-8. doi:10.1097/PRS.0b013e3181aeeb06.

4. De Castro R, Merlini E, Rigamonti W,Macedo A Jr. Phalloplasty and urethroplasty in children with penile agenesis: preliminary report. J Urol. 2007 Mar;177(3):1112-6; discussion 1117. PMID: 17296424.

5. Kwon TG, Yoo JJ, Atala A. Autologous penile corpora cavernosa replacement using tissue engineering techniques. J Urol.2002 Oct;168(4Pt2):1754-8. PMID: 12352353.

6. Dominici M, Le Blanc K, Mueller I, Slaper-Cortenbach I, Marini F, Krause D, Deans R, Keating A, Prockop D, Horwitz E. Minimal criteria for defining multipotent mesenchymal stromal cells. The 
International Society for Cellular Therapy position statement. Cytotherapy. 2006;8(4):315-7. PMID; 16923606.

7. Semedo P, Correa-Costa M, Antonio Cenedeze M, Maria Avancini Costa Malheiros D, Antonia dos Reis M, Shimizu MH, Seguro AC, Pacheco-Silva A, Saraiva Camara NO. Mesenchymal stem cells attenuate renal fibrosis through immune modulation and remodeling properties in a rat remnant kidney model. Stem Cells. 2009 Dec;27(12):3063-73.doi: 10.1002/stem214.

8. Semedo P, Palasio CG, Oliveira CD, Feitoza CQ, Gonçalves GM, Cenedeze MA, Wang PM, Teixeira VP, Reis MA, Pacheco-Silva A, Câmara NO. Early modulation of inflammation by mesenchymal stem cell after acute kidney injury. Int Immunopharmacol. 2009 Jun;9(6):677-82. doi;10.1016/j.intimp.2008.

9. Atoui R, Chiu RC. Concise review: immunomodulatory properties of mesenchymal stem cells in cellular transplantation: update, controversies, and unknowns. Stem Cells Transl Med. 2012 Mar;1(3):200-5. doi:10.5966/sctm.2011-0012.

10. Augello A, Kurth TB, De Bari C. Mesenchymal stem cells: a perspective from in vitro cultures to in vivo migration and niches. Eur Cell Mater. 2010 Sep;20:121-33. PMID: 21249629.

11. Di Nicola M, Carlo-Stella C, Magni M, Milanesi M, Longoni PD, Matteucci P, Grisanti S, Gianni AM. Human bone marrow stromal cells suppress T-lymphocyte proliferation induced by cellular or nonspecific mitogenic stimuli. Blood. 2002 May15;99:3838-43. PMID: 11986244

12. Bartholomew A, Sturgeon C, Siatskas M, Ferrerk K, McIntosh K, Patil S, Hardy W, Devine S, Ucker D, Deans R, Moseley A, Hoffman R. Mesenchymal stem cells suppress lymphocyte proliferation in vitro and prolong skin graft survival in vivo. Exp Hematol. 2002 Jan;30(1):42-8. PMID: 11823036.

13. Jiang X-X, Zhang Y, Liu B, Zhang SX, Wu Y, Yu SD, Mao N. Human mesenchymal stem cells inhibit differentiation and function of monocyte-derived dendritic cells. Blood. 2005 May;105(10):41206. PMID: 15692068.

14. Nauta AJ, Kruisselbrink AB, Lurvink E, Willenze R, Fibbe WE. Mesenchymal stem cells inhibit generation and function of both CD34+-derived and monocyte-derived dendritic cells. J Immunol. 2006 Aug15;177:2080-7. PMID: 16887966.

15. Ramasamy R, Fazekasova H, Lam EW, Soeiro I, Lombardi G, Dazzi F. Mesenchymal stem cells inhibit dendritic cell differentiation and function by preventing entry into the cell cycle. Transplantation. 2007 Jan15;83(1):71-6. PMID: 17220794.

16. Assis AC, Carvalho JL, Jacoby BA, Ferreira RL, Castanheira P, Diniz SO, Cardoso VN, Goes AM, Ferreira AJ. Time-dependent migration of systemically delivered bone marrow mesenchymal stem cells to the infarcted heart. Cell Transplant. 2010;19(2):21930. doi: 10.3727/096368909X479677.

17. Murphy JM, Fink DJ, Hunziker EB, Barry FP. Stem cell therapy in a caprine model of osteoarthritis. Arthritis Rheum. 2003 Dec;48(12):3464-74. PMID: 14673997.

18. Mackay AM, Beck SC, Murphy JM, Barry FP, Chichester CO, Pittenger MF. Chondrogenic differentiation of cultured human mesenchymal stem cells from marrow. Tissue Eng. 1998 Winter;4(4):415-28. PMID: 9916173.

19. Blanc KL, Frassoni F, Ball L, Locatelli F, Roelofs H, Lewis I, Lanino E, Sundberg B, Bernardo ME, Remberger M, Dini G, Egeler RM, Bacigalupo A, Fibbe W, Ringdén O. Mesenchymal stem cells for treatment of steroid-resistant, severe, acute graft-versus-host disease: a phase II study. Lancet. 2008 May 10;371(9624):1579-86. doi: 10.1016/S0140-6736(08)60690 - X.

20. Park HJ, Yoo JJ, Kershen RT, Moreland R, Atala A. Reconstitution of human corporal smooth muscle and endothelial cells in vitro. $\mathrm{J}$ Urol. 1999 Sep;162 (3Pt2):1106-09. PMID: 10458441.
21. Kershen RT, Yoo JJ, Moreland RB, Krane RJ, Atala A. Reconstitution of human corpus cavernosum smooth muscle in vitro and in vivo. Tissue Eng. 2002 Jul;8(3):515-24. PMID: 12167235.

22. Falke G, Yoo JJ, Kwon TG, Moreland R, Atala A. Formation of corporal tissue architecture in vivo using human cavernosal muscle and endothelial cells seeded on collagen matrices. Tissue Eng. 2003 Oct;9(5):871-9. PMID: 14633372.

23. Song LJ, Xu YM, Li C, Fu Q, Cui L, Hu XY. Construction of cavernosum smooth muscle using umbilical artery smooth muscle cells seeded on acellular corporal collagen matrices. Int J Androl. 2009 Oct;32(5):514-23. doi: 10.1111/j.1365-2605.2008.00888.x.

24. Luo JC, Chen W, Chen XH, Qin TW, Huang YC, Xie HQ, Li XQ, Qian XY, Yang ZM. A multi-step method for preparation of porcine small intestinal submucosa (SIS). Biomaterials. 2011Jan;32(3):70613. doi: 10.1016/j.biomaterials.2010.09.017.

25. Gao J, Dennis JE, Muzic RF, Lundberg M, Caplan AI. The dynamic in vivo distribution of bone marrow-derived mesenchymal stem cells after infusion. Cells Tissues Organs. 2001;169(1):12-20. PMID: 11340257.

26. Schrepfer S, Deuse T, Reichenspurner H, Fischbein MP, Robbins RC, Pelletier MP. Stem cell transplantation: the lung barrier. Transplant Proc. 2007 Mar;39(2):573-6. PMID: 17362785.

27. Leite MTC, Freitas-Fillho LG, Oliveira AS, Semedo-Kuriki P, Laks M, Arias WEA, Peixoto PS. The use of mesenchymal stem cells in bladder augmentation. Pediatr Surg Int. 2014 Apr;30(4):361-70. doi: 10.1007/s00283-014-3465-2.

28. Ji C, Min F, Liang W, Chen Y, Pan S, Bin L, Chen S, Wei Z, He T, Gu Y, Zhang J. Construction of tissue-engineered corpus cavernosum with muscle-derived stem cells and transplantation in vivo. BJU Int. 2011;107(10):1638-46. doi: 10.1111/j.1464-410X.2010.09695.x.

29. An G, Ji C, Wei Z, Chen H, Zhang J. Engineering of corpus cavernosum using vascular endothelial growth factor-expressing muscle-derived stem cells seeded on acellular corporal collagen matrices. Urology. 2013 Feb;81(2):424-31. doi: 10.1016/j. urology.2012.10.042.

\section{Correspondence:}

Luiz Gonzaga Freitas Filho

Rua Batista Cepelos, 87/61

04109-120 São Paulo - SP Brasil

Tel.: (55 11)5083-5952 / 8323-1299

luizfreitasepm@gmail.com

Received: Apr 7, 2015

Review: June 12, 2015

Accepted: July 152015

Conflict of interest: none

Financial source: none

${ }^{1}$ Research performed at Pediatric Surgical Research Laboratory, Universidade Federal de São Paulo (UNIFESP), Brazil. 